\title{
Frequency of chromosomal abnormalities in early embryos of the domestic sheep (Ovis aries)
}

\author{
Susan E. Long and C. V. Williams \\ Department of Animal Husbandry, University of Bristol, Langford House, Langford, \\ Bristol BS18 7DU, U.K.
}

\begin{abstract}
Summary. Embryos or unfertilized eggs were collected 2 or 3 days post coitum from mature sheep of various breeds and crosses. The karyotypes of 89 of the 376 collected were established. There were 44 embryos with $2 n=54 X X, 30$ with $2 n=54 X Y ; 1$ was a $2 n / 1 n$ mosaic; 4 had $2 n+1$ chromosomes giving an incidence of trisomy of $4.7 \%$; and 1 unfertilized egg had $n=28$. The incidence of chromosomal abnormalities was $6 \%$, and $1.3 \%$ of the eggs or embryos had a cracked zona pellucida.
\end{abstract}

\section{Introduction}

Early embryonic death in domestic animals represents a considerable economic loss. In sheep the wastage has been estimated to be $20-30 \%$ of all fertilized ova (Edey, 1969). Similar levels of embryonic loss have been reported in the pig (Hanly, 1961) and cow (Boyd, Bacsich, Young \& McCracken, 1969). Such losses are exclusive of those caused by infectious conditions and have been attributed to a number of factors (for reviews, see Boyd, 1965; Edey, 1969). Bishop (1964) suggested that a proportion of the loss might be due to an abnormal genetic load rendering the embryo non-viable. A high proportion of spontaneous human abortuses have a chromosomal abnormality and it has been assumed that some of the embryonic loss in domestic animals has a similar aetiology. Chromosomally abnormal embryos have been reported in the pig (McFeely, 1967; Smith \& Marlow, 1971; Ákesson \& Henricson, 1972; Moon, Rashad \& Mi, 1975) and the cow (McFeely \& Rajakoski, 1968), but examination of preimplantation blastocysts in sheep failed to detect any with such abnormalities (Long, 1977). Of the embryos studied by Long (1977), 25\% were undiagnosed and it was suggested that abnormal embryos may have been degenerating by the late preimplantation stage and that more accurate information would be obtained from an examination of earlier embryos. A preliminary investigation revealed the presence of some 2-day post coitum sheep embryos with chromosomal abnormalities (Long \& Williams, 1978). The present paper presents further information on the incidence of chromosomally abnormal embryos from $54 \mathrm{XX}$ ewes mated to $54 \mathrm{XY}$ rams.

\section{Materials and Methods}

The work was carried out during the breeding seasons of 1976-1978. The 162 mature ewes of various breeds (Table 1) were naturally mated to a Suffolk or Clun ram. The chromosome complement of all the ewes and rams was established by routine lymphocyte culture.

Embryos and unfertilized eggs were collected 2 or 3 days post coitum at laparotomy and post mortem. At 2 days post coitum the embryos were at the 2-4-cell stage, whereas by Day 3 they had reached the 8-cell stage. Collection at laparotomy was by retrograde flushing of the oviducts (Long \& Williams, 1978). After surgery the ewes were returned to the flock and were mated again at the next oestrus. The ewes were slaughtered 2-3 days after this second service and the embryos and eggs were collected post mortem. 
Table 1. Breeds of sheep used for egg collection

\begin{tabular}{lc}
\hline \multicolumn{1}{c}{ Breed } & No. of ewes \\
\hline Scottish halfbred & 40 \\
Clun cross & 30 \\
Suffolk cross & 26 \\
Dorset horn $\times$ Scottish halfbred & 25 \\
Dorset down $\times$ Finnish Landrace & 9 \\
Mashams & 19 \\
Welsh Mountain & 13 \\
\hline
\end{tabular}

The embryos, fertilized and unfertilized eggs were cultured for $24 \mathrm{~h}$ in medium containing colchicine to accumulate cells at metaphase and chromosome preparations were made as previously described (Long \& Williams, 1978). The slides were stained with a 1:10 Giemsa (Gurr R66): phosphate- buffered saline solution, pH 6·8, for 5-15 min.

\section{Results}

The chromosome complements were $2 \mathrm{n}=54 \mathrm{XX}$ for all the ewes and $54 \mathrm{XY}$ for all the rams. $\mathrm{A}$ total of 376 eggs or embryos was collected: $5(1.3 \%)$ had a cracked zona pellucida ( 3 of these were unfertilized eggs (Pl. 1, Fig. 1) and 2 were 8-cell embryos (Pl. 1, Fig. 2)) and 209 (56.3\%) of the remaining 371 had mitotic metaphase chromosomes. Only $35 \%$ of the unfertilized eggs and $41 \%$ of the 8 -cell embryos went into cell division, whereas $87 \%$ of the $2-6$-cell embryos began to divide in culture: 89 of those dividing $(42.6 \%)$ produced metaphase spreads suitable for karyotype analysis (Table 2). The remainder were discarded because of overlapping or excess spreading. There were 44 embryos with $2 \mathrm{n}=54 \mathrm{XX}$ and 30 with $2 \mathrm{n}=54 \mathrm{XY}$. This was not a statistically significant difference from a $1: 1$ ratio $\left(\chi^{2}=2.64 ; 0.1<P<0.2\right)$.

Table 2. Chromosome complements of eggs and embryos from $54 \mathrm{XX}$ ewes mated to $54 \mathrm{XY}$ rams

\begin{tabular}{lccccc}
\hline Chromosome no. & $27 \mathrm{X}$ & $54 \mathrm{XX}$ & $54 \mathrm{XY}$ & Abnormal & Total \\
No. of eggs or embryos & 2 & 44 & 30 & 13 & 89 \\
\hline
\end{tabular}

Thirteen of the $89(14.6 \%)$ were considered to deviate from the normal; 1 egg (28X) showed evidence of non-disjunction at meiotic anaphase I (Pl. 2, Fig. 3); 1 embryo appeared to be a 2n/1n mosaic; 4 embryos (2 with 55XY, 2 with 55XX) had an extra chromosome (Pl. 2, Fig. 4); 1 single-cell zygote (54XX) had a chromatid break in the long arm of chromosome number 1 ; and the remaining abnormalities ( 2 with $26 \mathrm{X}, 1$ with $53 \mathrm{XX}, 2$ with $53 \mathrm{Y}$ and 1 with $53 \mathrm{X}$ ) were deficiencies of whole chromosomes.

\section{Discussion}

The present work confirms the earlier finding (Long \& Williams, 1978) that chromosomally abnormal sheep embryos are present at 2 days post coitum. However, the results need to be interpreted with caution. The nature of the technique is such that individual chromosomes are easily lost during the spreading process. Therefore, since none of the hypomodal eggs or embryos was diagnosed on spreads from more than one blastomere, the possibility that these 


\section{PLATE 1}

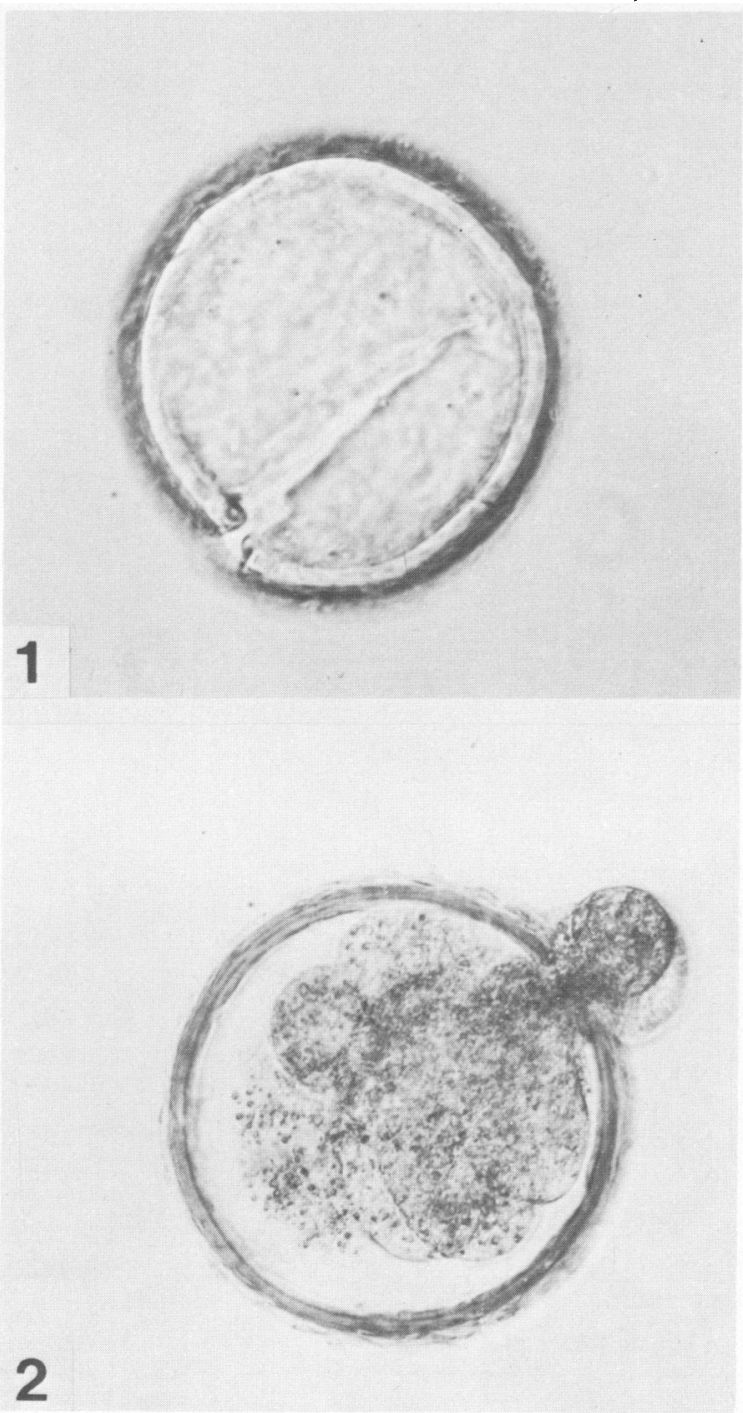

Fig. 1. An unfertilized sheep egg with a cracked zona pellucida.

Fig. 2. An 8-cell sheep embryo with a cracked zona pellucida. 
PLATE 2

\section{$r$}

I

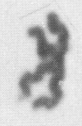

2

\section{8}

Nin $R$

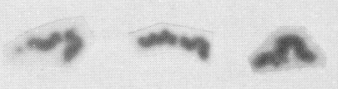

3

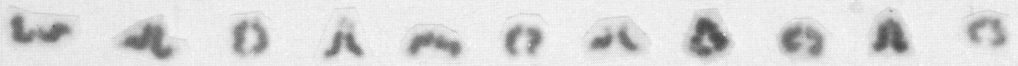

Fig. 3
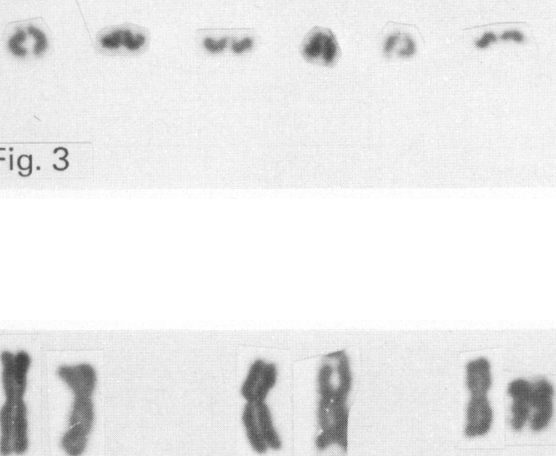

ด 0 a

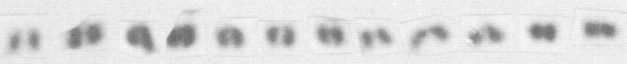

Fig. 4

Fig. 3. Karyotype from an unfertilized sheep egg with 28 chromosomes.

Fig. 4. Karyotype from an 8-cell sheep embryo with 55 chromosomes. The arrow indicates a chromatid break. 
were technical artefacts cannot be excluded. Similarly, it is well recognized that such defects as chromatid breaks may be due to viral contamination of the culture medium (Fechheimer, 1971, 1972). Even relatively mịnor changes in specific cultural conditions can give rise to enhanced secondary constrictions (Palmer \& Funderburk, 1965; Bruère \& McLaren, 1967). These considerations make it impossible to draw firm conclusions from the present data on the incidence of such abnormalities as autosomal or X monosomy.

The presumptive $2 n / 1 n$ mosaic embryo is extremely interesting. The preparation showed two clear diploid spreads and one haploid (27X) spread. The haploid spread could not have been from a normal polar body since, in our experience, the chromosomes from these are much more elongated and spidery. One possibility is that this was a dispermic egg and the haploid spread was from the extra male pronucleus. A true $2 n / 1 n$ mosaic has been seen in a mouse morula (E. P. Evans, personal communication). Again, the haploid spreads were female so that their origin remained obscure.

The finding of four $2 n+1$ embryos gave an incidence of trisomy in the diagnosed material of $4.7 \%$. In each case the extra chromosome was an acrocentric. It was tentatively identified as an autosome but definite identification was not possible. C-banding was attempted with some preparations using the method described by Sumner (1972) but was unsuccessful.

Such trisomic individuals may arise as a result of non-disjunction at the first or second meiotic division in the formation of an ovum or spermatozoon. In man, for example, the extra chromosome 21 in Down's syndrome has been shown to be of maternal or paternal origin, although with differing frequencies. It can also arise at metaphase I or metaphase II (Jacobs \& Morton, 1977; Hansson \& Mikkelsen, 1978). No information is available on the source of the extra chromosomes in the sheep embryos.

The 1-cell egg with 28 chromosomes in the present work had an extra acrocentric autosome since the $\mathrm{X}$ and three metacentric chromosomes were clearly identifiable (Pl. Fig. 3). Direct calculations of non-disjunction at metaphase $I$ in the ewe have not been made since only a few cells at meiotic metaphase II have been successfully analysed (Logue, 1977). However, estimates from the present data suggest that the incidence of ova with the extra chromosome lies in the range of $1-5 \%$. Calculations of autosomal non-disjunction in the ram from reports in the literature (Table 3 ) give a mean value of $2.8 \%$ using the formula: no. of (hyperhaploid cells $\times 2$ $\times 100) /$ total no. of cells counted. The level of trisomy found in the present study is therefore compatible with current estimates for non-disjunction in the gametes.

Table 3. Distribution of chromosome number at meiotic second metaphase in $54 X Y$ rams

\begin{tabular}{ccccccccc}
\hline & & \multicolumn{3}{c}{ No. of chromosomes } & & Total no. \\
\cline { 3 - 7 } Authors & No. of animals & $<25$ & 25 & 26 & 27 & 28 & of cells \\
\hline $\begin{array}{c}\text { Chapman \& Bruère (1975) } \\
\text { Logue (1977) }\end{array}$ & 10 & 6 & 1 & 3 & 52 & 0 & 62 \\
Long (1978) & 2 & 0 & 3 & 8 & 42 & 2 & 55 \\
\hline & 1 & 0 & 2 & 10 & 86 & $2^{*}$ & 100 \\
\hline
\end{tabular}

* One cell of $28 \mathrm{X}$ and one of $28 \mathrm{XY}$.

If only hypermodal eggs and embryos are considered, since these were unlikely to have been technical artefacts, the incidence of chromosomal abnormalities was $6 \%(5 / 84)$. This compares with the values of 11 and $8 \%$ reported in preimplantation blastocysts of pigs (McFeely, 1967) and cattle (McFeely \& Rajakoski, 1968) respectively. Results from work with laboratory animals have been reviewed by Ford (1975) and show a similar low incidence. 
The abnormalities found in sheep embryos differ from those reported in the pig in which polyploidy, predominantly triploidy and tetraploidy, has been the most common finding (McFeely, 1967; Moon et al., 1975). In addition, the one abnormal bovine blastocyst has been described as a diploid/tetraploid mosaic (McFeely \& Rajakoski, 1968). Polyploid cells have also been found in pig blastocysts, 10 days post coitum, by N. S. Fechheimer (personal communication) who suggested that these may have originated from trophoblast cells rather than from the inner cell mass. Giant cells and binucleate cells are present in the pig trophoblast at this stage (E. C. Polge, personal communication). By contrast, binucleate cells do not appear in the sheep trophoblast until Day 16 (Boshier, 1969) and have not been reported in the cow trophoblast until Day 17 of gestation (Greenstein, Murray \& Foley, 1958).

It is, however, possible that the polyploid embryos in the pig may have arisen due to ageing of the ova after ovulation. Ageing of gametes is known to increase the incidence of triploidy (Shaver \& Carr, 1967, 1969), with ageing of ova being the more important (Fechheimer \& Beatty, 1974). In addition, ageing of spermatozoa in utero increases the incidence of mixaploid blastocysts in the rabbit (Martin \& Shaver, 1972).

Differences in the duration of oestrus and times of ovulation in domestic animals may be important in that they will influence the likelihood of abnormal embryos arising. Animals such as ewes or cows, which have short oestrous periods and ovulate after the female ceases to accept coitus, are less likely to incur ovum ageing and hence the production of triploid embryos than, for example, sows or mares in which oestrus continues for several days and the female will accept coitus even after ovulation has occurred. The incidence of trisomy, however, depends on the incidence of non-disjunction in the gametes and is not dependent on the time of fertilization.

The incidence of chromosomally abnormal embryos in domestic animals is probably lower than that in man. Estimates from data from surveys of chromosomal abnormalities in newborn infants (Sergovich, Valentine, Chen, Kinch \& Smout, 1969; Lubs \& Ruddle, 1970; Hamerton, Canning, Ray \& Smith, 1975) and from spontaneous abortuses (Boué, Boué \& Lazar, 1975; Alberman \& Creasy, 1977) suggest that $7-8 \%$ of recognized pregnancies have a chromosomal abnormality. However, this is almost certainly an underestimate of the incidence at conception, which has been placed as high as $50 \%$ by some workers (Boué et al., 1975). In the sheep, not all the early embryonic loss can be attributed to gross chromosomal abnormalities. However, as techniques of chromosome identification improve they may reveal the existence of more minor chromosomal re-arrangements which are incompatible with life.

One final result of interest is the $1.3 \%$ of eggs or embryos found with a cracked zona pellucida. It is difficult to know whether these were present in vivo. They could not have represented the normal degeneration of unfertilized eggs since many such eggs were collected with an intact zona. Trounson \& Moore (1974) have shown that mechanical rupture of the zona of 2- and 3-day embryos seriously impairs their potential for development. It may be that such abnormalities of the zona are a further cause of early embryonic loss in the sheep.

We should like to thank Professor N. S. Fechheimer, Dr E. P. Evans and Dr C. Polge for useful information and helpful criticism of the paper. The work was supported by a grant from the Agricultural Research Council.

\section{References}

Ákesson, A. \& Henricson, B. (1972) Embryonic death in pigs caused by an unbalanced karyotype. Acta vet. scand. 13, 151-160.

Alberman, E.D. \& Creasy, M.R. (1977) Frequency of chromosomal abnormalities in miscarriages and perinatal deaths. J. med. Genet. 14, 313-315.

Bishop, M.W.H. (1964) Paternal contribution to embryonic death. J. Reprod. Fert. 7, 383-396.
Boshier, D.P. (1969) A histological and histochemical examination of implantation and early placentome formation in sheep. J. Reprod. Fert. 19, 57-61.

Boyd, H. (1965) Embryonic death in cattle, sheep and pigs. Vet. Bull. 35, 251-266.

Boyd, H., Bacsich, P., Young, A. \& McCracken, J.A. (1969) Fertilisation and embryonic survival in dairy cattle. Br.vet.J. 125, 87-97. 
Boué, J., Boué, A. \& Lazar, P. (1975) The epidemiology of human spontaneous abortions with chromosomal anomalies. In The Biology and Pathology of Ageing Gametes, pp. 330-348. Ed. R. J. Blandau. Karger, Basel.

Bruère, A.N. \& McLaren, R.D. (1967) The idiogram of the sheep with particular reference to secondary constrictions. Can. J. Genet. Cytol. 9, 543-553.

Chapman, H.M. \& Bruère, A.N. (1975) The frequency of aneuploidy in the secondary spermatocytes of normal and Robertsonian translocation carrying rams. J. Reprod. Fert. 45, 333-342.

Edey, T.N. (1969) Prenatal mortality in sheep; a review. Anim. Breed. Abstr. 37, 43-58.

Fechheimer, N.S. (1971) Cytogenetic considerations in animal breeding. Ann. Genet. Sel. anim. 3, 43-58.

Fechheimer, N.S. (1972) Causal basis of chromosome abnormalities. J. Reprod. Fert., Suppl. 15, 79-98.

Fechheimer, N.S. \& Beatty, R.A. (1974) Chromosomal abnormalities and sex ratio in rabbit blastocysts. $J$. Reprod. Fert. 37, 331-341.

Ford, C.E. (1975) The time in development at which gross genome unbalance is expressed. In The Early Development of Mammals, pp. 285-304. Eds M. Balls \& A. E. Wild. Cambridge University Press.

Greenstein, J.S., Murray, R.W. \& Foley, R.C. (1958) Observations on the morphogenesis and histochemistry of the bovine pre-attachment placenta between 16 and 33 days of gestation. Anat. Rec. 132, 321-341.

Hamerton, J.L., Canning, N., Ray, M. \& Smith, S. (1975) A cytogenetic survey of 14,069 newborn infants. 1. Incidence of chromosome abnormalities. Clin. Genet. 8, 223-243.

Hanly, S. (1961) Prenatal mortality in farm animals. $J$. Reprod. Fert. 2, 182-194.

Hansson, A. \& Mikkelsen, M. (1978) The origin of the extra chromosome 21 in Down's syndrome. Studies of fluorescent variants and satellite association in 26 informative families. Cytogenet. Cell Genet. 20, 194-203.

Jacobs, P.A. \& Morton, N.E. (1977) Origin of human trisomics and polyploids. Hum. Hered. 27, 59-72.

Logue, D.N. (1977) Meiosis in the domestic ruminants with particular reference to Robertsonian translocations. Ann. Genet. Sel. Anim. 9, 493-507.

Long, S.E. (1977) Cytogenetic examination of preimplantation blastocysts of ewes mated to rams heterozygous for the Massey I $\left(t_{1}\right)$ translocation. Cytogenet. Cell Genet. 18, 82-89.
Long, S.E. (1978) Chiasma counts and non-disjunction frequencies in a normal ram and rams carrying the Massey I $\left(\mathrm{t}_{1}\right)$ Robertsonian translocation. J. Reprod. Fert. 53, 353-356.

Long, S.E. \& Williams, C.V. (1978) Chromosomal abnormalities in ova and zygotes from normal ewes mated to normal rams. Vet. Rec. $102,153$.

Lubs, H.A. \& Ruddle, F.H. (1970) Applications of quantitative karyotype to chromosome variation in 4,400 consecutive newborns. In Human Population Cytogenetics, pp. 119-142. Eds P. A. Jacobs, W. H. Price \& P. Law. Edinburgh University Press.

Martin, P.A. \& Shaver, E.L. (1972) Sperm ageing in utero and chromosomal anomalies in rabbit blastocysts. Devl. Biol. 28, 480-486.

McFeely, R.A. (1967) Chromosome abnormalities in early embryos of the pig. J. Reprod. Fert. 13, 579581 .

McFeely, R.A. \& Rajakoski, E. (1968) Chromosome studies on early embryos of the cow. Proc. 6th Int. Congr. Anim. Reprod. \& A.I., Paris 2, 905-907.

Moon, R.G., Rashad, M.N. \& Mi, M.P. (1975) An example of polyploidy in pig blastocysts. J. Reprod. Fert. 45, 147-149.

Palmer, C.G. \& Funderburk, S. (1965) Secondary constrictions in human chromosomes. Cytogenetics 4, 261-276.

Sergovich, F., Valentine, G.H., Chen, A.T.L., Kinch, R.A.H. \& Smout, M.S. (1969) Chromosome aberrations in 2,159 consecutive newborn babies. New Engl. J. Med. 280, 851-855.

Shaver, E.L. \& Carr, D.H. (1967) Chromosome abnormalities in rabbit blastocysts following delayed fertilisation. J. Reprod. Fert. 14, 415-420.

Shaver, E.L. \& Carr, D.H. (1969) The chromosome complement of rabbit blastocysts in relation to the time of mating and ovulation. Can. J. Genet. Cytol. 11, 287-293.

Smith, J.H. \& Marlowe, T.J. (1971) A chromosomal analysis of 25-day-old pig embryos. Cytogenetics 10 , 385-391.

Sumner, A.T. (1972) A simple technique for demonstrating centromeric heterochromatin. Expl Cell Res. 75, 304-306.

Trounson, A.O. \& Moore, N.W. (1974) The survival and development of sheep eggs following complete or partial removal of the zona pellucida. J. Reprod. Fert. 41, 97-105.

Received 4 May 1979 